\title{
The availability of specialised quit support provided by the national stop-smoking program in Romania
}

Valentin Nădășan*, Andreea-Maria Coc, Loránd Ferencz, Zoltán Ábrám

Department of Hygiene and Environmental Health, George Emil Palade University of Medicine, Pharmacy, Science, and Technology of Targu Mures, Targu Mures, Romania

Abstract

English:

Introduction: Quit-smoking support is provided to Romanian smokers since 2007 through a network of stop-smoking centres. The study aimed to collect up-to-date information about the availability of psychological counselling and medication for smoking cessation at the existing specialised centres.

Materials and methods: All the stop-smoking centres listed on the program's official website were contacted by phone by a trained evaluator introducing himself as a smoker in need of professional support.

Results: Of the 41 counties listed on the website, only $70.7 \%$ provided a contact phone number for the stop-smoking centre. While $56.1 \%$ of the centres answered the first or second call, the actual availability of quit support was confirmed by only $41.5 \%$ of the centres. The time till the first appointment varied between 1 day and 1 month. Psychological support and free medication for treating nicotine addiction were available in $36.6 \%$ and $14.6 \%$ of the centres, respectively.

Conclusion: The availability of stop-smoking support at the time of the assessment was significantly limited.

Keywords

\section{Disponibilitatea asistenței specializate pentru renunțare la fumat furnizată de Programul Național Stop-fumat în România}

Rezumat
Romanian:
Introducere: Fumătorii din România beneficiază de asistență pentru renunțarea la fumat din anul 2007 prin rețeaua de centre Stop-fumat. Studiul a avut ca obiectiv colectarea de date la zi despre disponibilitatea consilierii și medicației pentru tratarea dependenței de nicotină la nivelul centrelor specializate existente.
Material și metodă: Centrele Stop-fumat au fost contactate telefonic de către un evaluator instruit care s-a prezentat ca un fumător care are nevoie de asistență specializată.
Rezultate: Din totalul de 41 de județe găsite pe website-ul programului național, doar $70,7 \%$ au avut un număr telefonic de con- tact pentru centrul stop-fumat. În timp ce 56,1\% dintre centre au răspuns la primul sau al doilea apel, disponibilitatea efectivă a asistentei pentru renunțare la fumat a fost confirmată în numai $41,5 \%$ dintre centre. Intervalul de timp până la prima consultație programată a variat de la o zi până la o lună. Consilierea psihologică și terapia farmacologică a dependenței de nicotină au fost disponibile în $36,6 \%$ respectiv $14,6 \%$ dintre centre.
Concluzie: La momentul evaluării, disponibilitatea asistenței specializate în centrele stop-fumat a fost limitată în mod semnificativ.

Cuvinte-cheie

tutun • asistență stop-fumat • Programul Național Stop-fumat • România • Convenția-Cadru pentru Controlul Tutunului 


\section{Introduction}

Tobacco use is a major cause of premature mortality worldwide, resulting in approximately sevenmillion preventable deaths annually (1). The European Region had the highest prevalence of tobacco use in the world in 2019 , with a $29 \%$ of population reported as current smokers (2). In Romania, the 2018 Global Adult Tobacco Survey country report has shown that $30.2 \%$ of the adults are current smokers (3).

The World Health Organization Framework Convention on Tobacco Control (WHO FCTC) adopted in 2003 includes evidence-based strategies to reduce both demand and supply issues. Article 14 of the WHO FCTC calls on treaty parties to implement programs designed to treat tobacco dependence. The aim of tobacco dependence treatment is to help tobacco users stop their tobacco use. Tobacco dependence treatment should include behavioural support or medications, or both. Behavioural support is defined as support other than medications, aimed at helping people stop their tobacco use, and it can include cessation assistance that imparts knowledge about tobacco use and quitting, provides support and teaches skills and strategies for changing behaviour (4). The guidelines for implementation of Article 14 of the WHO FCTC recommend parties to create a sustainable infrastructure that ensures widely available and affordable tobacco dependence treatment. These services should be as inclusive as possible, taking into consideration factors such as gender, culture, religion, age, educational background, literacy, socioeconomic status and disability (5).

Romania has ratified the WHO FCTC in 2005, and 2 years later, a National Stop-Smoking program was established under the authority of the Romanian Ministry of Health. The specialised centres located in most of the larger cities of Romania employ specially trained physicians and psychologists coordinated by the "Marius Nasta" Pulmonology Institute. The program aims to provide smokers a comprehensive quit-smoking assistance combining psychological counselling with pharmacological therapy. The cognitive-behavioural support and pharmacological treatment comply with the WHO's recommendations $(6,7)$.

\section{Objective}

The study aimed to collect up-to-date information about the availability of stop-smoking counselling and medication at the specialised centres working within the Romanian National Stop-Smoking Program.

\section{Materials and methods}

The study sample included all the stop-smoking centres in Romania according to the listing found on the official website of the program (stopfumat.eu). Each centre was contacted by phone, during 7-9 December 2018. The first round of calls was made in the afternoon hours. Centres that could not be reached at the first attempt were approached the next day in the course of the morning hours. The evaluator introduced himself as a 22-year-old smoker, who had been smoking for 3 years, tried quitting on his own with no success and seeks professional support to stop smoking. The evaluator was trained to passively retain or, if needed, actively ask for the following information:

a) whether cessation services were actually offered to the smoker;

b) time till the first appointment granted to the smoker;

c) whether the services included professional counselling;

d) whether the services included stop-smoking medication and

e) whether the medication was offered free of charge or at the smoker's expense.

The answers were recorded during or immediately after the phone call. Data were later centralised and coded in an Excel file, and the absolute and relative frequencies were calculated for each answer to each question.

The research was conducted according to the ethical principles of the Declaration of Helsinki on the medical research involving human subjects.

\section{Results}

The total number of counties listed on the program's official website (stopfumat.eu) was 41 . Ilfov county was listed at the same entry as the capital city Bucharest. No phone number or other contact data could be retrieved from the website for the following 12 counties: Bacău, Bistrița-Năsăud, Botoșani, Buzău, Caraș-Severin, Călărași, Giurgiu, Harghita, Mehedinți, Olt, Satu Mare and Vâlcea.

When selecting the name of these counties, the following warning was displayed: "There are no centres in the selected county". The geographical distribution of the counties with missing contact data is represented in Figure 1.

Of the 29 centres displaying a phone number, 17 (41\%) could be reached at the very first attempt during the afternoon hours, six (15\%) answered only at the second attempt during the morning hours on the next day, and six (15\%) did not answer on either attempt. 
Of the 17 centres that answered the smoker's call, 12 centres ( $41 \%$ of the total number of counties) confirmed that they can provide assistance, while six centres $(15 \%$ of the total number of counties) declared that the requested quit support is no more available at the respective centre.

The evaluator was able to get an appointment during the phone call in $15(88 \%)$ cases out of 17 centres that could be reached by phone. The mean number of days the smoker had to wait until the day of appointment was 9 days. The distribution of waiting times for the first appointment at the centre's location is presented in Figure 2.

Specialised psychological counselling and stop-smoking medication were offered by $15(37 \%)$ centres. The medication was offered free of charge in six (15\%) centres and on a payment base in nine (22\%) centres.

A synopsis of the findings is presented in Figure 3.

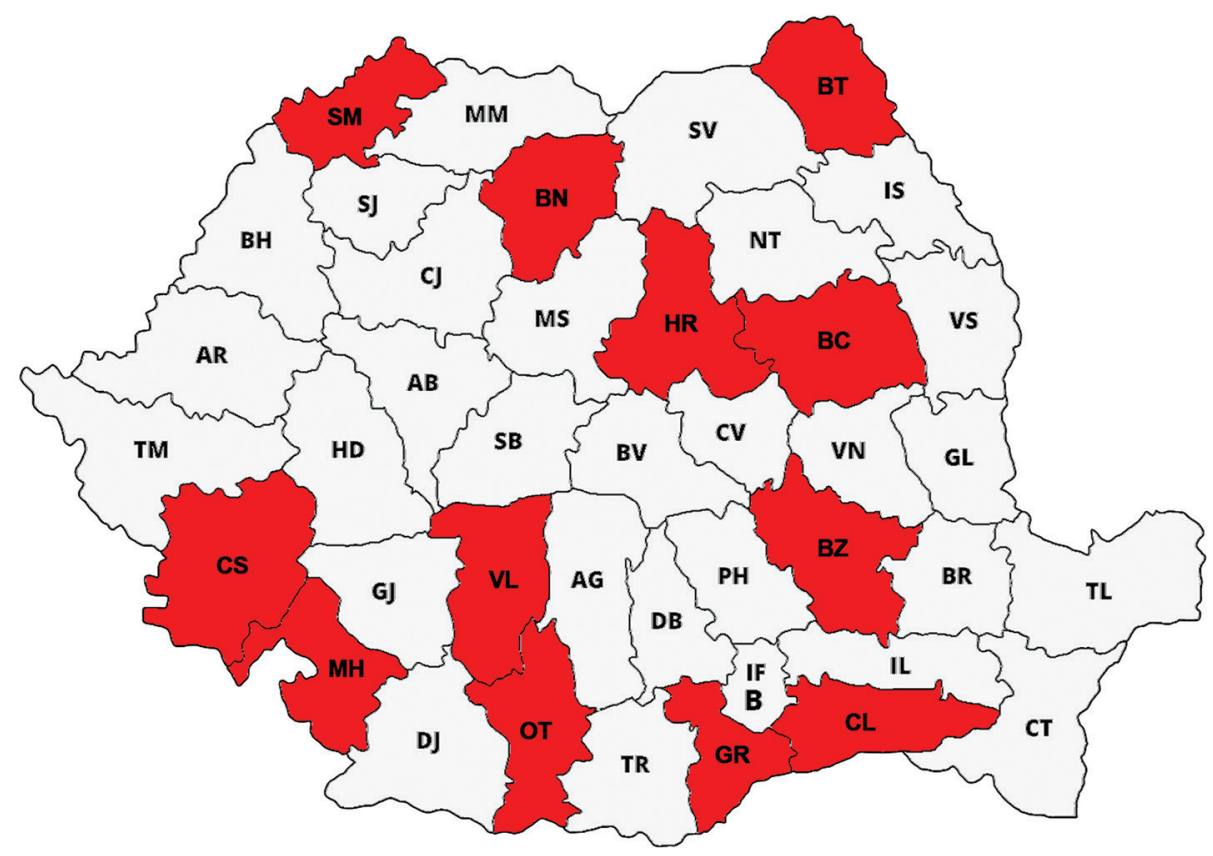

Figure 1. Geographical distribution of counties with centres without contact data on the program's website (counties with no contact data are represented in red).

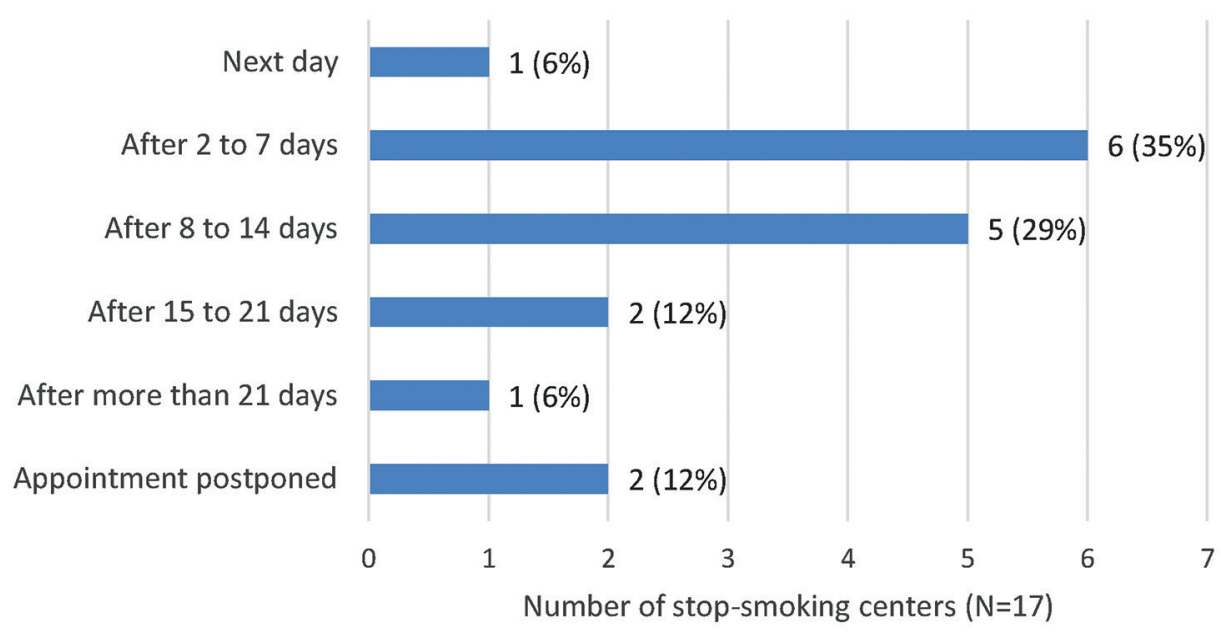

Figure 2. Waiting times till the first appointment. 


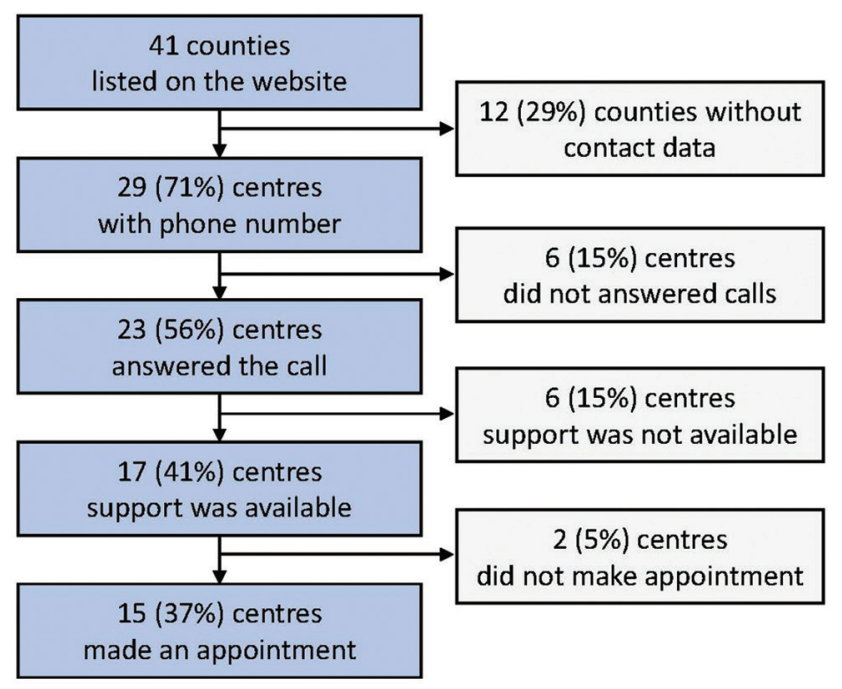

Figure 3. Synoptic view of the study findings.

\section{Discussions and conclusions}

The most notable steps taken in Romania for the implementation of Article 14 of the WHO FCTC included the development of a nationwide infrastructure of stopsmoking centres offering professional behavioural support and tobacco addiction treatment, the provision of a nationally accessible toll-free quit line, the development and dissemination of comprehensive guidelines adapted to the national circumstances and the introduction of designated tobacco taxes to sustain the national tobacco control strategy (7). However, the results of our evaluation suggest that the implementation recommendations described in Article 14 of the WHO FCTC through the National Stop-Smoking Program is significantly limited.

First, an important number of centres seem to have dropped out of the program, and therefore, many smokers in their allotted area are denied access to the assistance they need.

Second, geographical coverage seems uneven as stopsmoking centres are missing in almost one-third of the counties in Romania, as indicated by the lack of contact information on the program's official websites. Notwithstanding that some smokers seeking assistance to quit may be able to travel to the neighbouring county's centre, the absence of functional stop-smoking centres in some of the counties may create inequity issues especially for those smokers who cannot afford the cost of longer travels due to a lower income or poor public transportation connections, as suggested by studies on socioeconomic determinants of quit intentions, attempts and success $(8,9)$.

In the third place, in many instances, getting on the line with the specialised health professionals at the stop-smoking centres was not possible at the most convenient hours for a typical employee, which may further limit the access of some smokers to the quit services.

Finally, while all the centres that confirmed the availability of the stop-smoking services offered both behavioural support and medication, a majority of them were not able to provide free medication. Out-of-pocket costs may additionally amplify income-related inequities in the delivery of professional assistance to smokers and negatively influence utilisation of stop-smoking services and quit rates (10).

Although our study did not investigate the underlying factors of the observed issues, we can reasonably assume that the most likely causes of the limited availability of the stopsmoking services are related to insufficient funding of the program, and an irregular and unpredictable way of covering the costs of services by the financing institutions.

Data should be interpreted with caution, keeping in mind some of the methodological limitations. The cross-sectional design of the study did not allow us to gain insights into the trends of the investigated issues. The limited number of call attempts may have unwantedly produced a higher number of unanswered calls. The collection of data via telephone and post-call documentation of the answers may have led to some data inaccuracies. One last factor that could have possibly increased the number of instances the request of the evaluator was turned down is the fact that given the shortage of professionals and their time constraints, they might have treated lightly a request coming from a person of young age. In conclusion, the availability of stop-smoking specialised pharmacological and non-pharmacological support offered through the National Stop-Smoking Program in Romania was less than optimal. Investigations to identify the underlying causes and appropriate interventions to increase the availability of quit services seem warranted.

\section{Acknowledgement}

We thank Dr. Magdalena Ciobanu, the coordinator of the National Stop-Smoking Program, for critically reviewing the manuscript and her valuable suggestions.

\section{Conflict of interest}

The authors declare that they have no conflicts of interest.

\section{Ethical approval}

Taking into account the design and methodology of the study, no ethical approval was deemed necessary. However, all 
authors involved in data collection and processing have taken all the necessary precautions to conduct the investigation in compliance to the principles of the Declaration of Helsinki on the medical research involving human subjects.

\section{References}

1. Chung-Hall J, Craig L, Gravely S, Sansone N, Fong GT. Impact of the WHO FCTC over the first decade: A global evidence review prepared for the Impact Assessment Expert Group. Tobacco Control. 2019;28: s119-s128.

2. World Health Organization, Regional Office for Europe. European Tobacco Use Trends Report 2019. Copenhagen, 2019.

3. World Health Organization. GATS - Global Adult Tobacco Survey, Fact Sheet, Romania, 2018.

4. World Health Organization. WHO Framework Convention on Tobacco Control. 2003. Available from: http://apps.who.int/iris/ bitstream/10665/42811/1/9241591013.pdf?ua=1 [Accessed 5th October 2019].
5. World Health Organization. Guidelines for implementation of Article 14. Available from: https://www.who.int/fctc/guidelines/ adopted/article_14/en/ [Accessed 5th October 2019].

6. Societatea Română de Pneumologie. Ghid de renunțarea la fumat și asistență de specialitate a fumătorului. Ed. 2-a. Editura Tehnopress, lași, 2010.

7. Despre programul naţional STOP FUMAT. Available from: https://stopfumat.eu/despre-programul-national-stop-fumat/ [Accessed at 5.10.2019].

8. Reid JL, Hammond D, Boudreau C, Fong GT, Siahpush M; ITC Collaboration. Socioeconomic disparities in quit intentions, quit attempts, and smoking abstinence among smokers in four western countries: findings from the International Tobacco Control Four Country Survey. Nicotine \& Tobacco Research. 2010;12(Suppl): S20-S33.

9. Barbeau EM, Krieger N, Soobader MJ. Working class matters: socioeconomic disadvantage, race/ethnicity, gender, and smoking in NHIS 2000. American Journal of Public Health. 2004;94: 269-278.

10. Tinkelman D, Wilson SM, Willett J, Sweeney CT. Offering free NRT through a tobacco quitline: impact on utilisation and quit rates. Tobacco Control. 2007;16(Suppl. 1): i42-i46. 